\title{
Legal status of the president of the court as a judge and organizer of judicial activities: Structure and models
}

Ya. B. Zholobov ${ }^{1}$, V.N.Kornev ${ }^{2}$

${ }^{1}$ The North-Western branch of the Russian State University of Justice, 5, Alexandrovskii Park, St. Petersburg, 197046, Russian Federation

2 Russian State University of Justice, 69, Novocheryomushkinskaya ul., Moscow, 117418, Russian Federation

For citation: Zholobov, Yaroslav B., Viktor N. Kornev. 2021. "Legal status of the president of the court as a judge and organizer of judicial activities: Structure and models". Vestnik of Saint Petersburg University. Law 4: 921-934. https://doi.org/10.21638/spbu14.2021.407

The article considers the structure of the legal status of the president of a general jurisdiction court in the Russian Federation. The authors show that the term "legal status" is much more appropriate for court presidents than "legal position" and "legal state". A structure of the legal status of the president of a general jurisdiction court consisting of five elements is proposed: the procedure for appointment; guarantees of judicial activity determining the peculiarities of the court president's legal status compared to other holders of state power; competence of the court president; procedure for activity termination; responsibility. The article shows that though the legal status of the president is derived from the legal status of a judge, it has significant differences since a judge is assumed to have experience in professional activities, unique personal qualities, organizational and communicative skills, and therefore it is necessary to consider the professional and titular legal status of the court president. The key challenges associated with the development of the legal status of the president of a general jurisdiction court in Russia are identified, such as the lack of a clear hierarchy of sources where international legal standards are present in regard to both a mandatory and advisory nature, various legal acts, decisions of judicial bodies, documents from the judicial community; many issues determining the legal status of presidents of general jurisdiction courts are duplicated in a number of sources; the powers of court presidents can be determined in documents that, at first glance, regulate completely different types of public relations (enforcement proceedings, combating corruption, preventing child neglect and juvenile offences, etc.). The work proposes ways to improve the regulatory framework governing the legal status of the president of a general jurisdiction court in Russia.

Keywords: legal status, court president, courts of general jurisdiction, elements of legal status, legal position, legal state.

\section{Introduction}

In the 1990s, as part of a wide-ranging legal reorganization in the Russian Federation, judicial reform began; one of its goals was to determine the legal status of presidents of general jurisdiction courts.

General jurisdiction courts constitute the backbone of the Russian judicial system. However, in recent years, this system has repeatedly changed. The reform of the general jurisdiction courts in the Russian Federation led, first of all, to the exclusion of the Su-

(C) St. Petersburg State University, 2021 
preme Court of the Russian Federation from their system in 2014, as well as the inclusion of general jurisdiction courts of cassation and appeal in 2018. Consequently, such changes were reflected in the legislation on the judicial system and judicial proceedings, including the provisions determining the status and functions of presidents of general jurisdiction courts.

General jurisdiction courts (including military ones) are determined on territorial, subject-matter and personal jurisdiction. The unity of the system of general jurisdiction courts lies in the legislative consolidation of the primary conditions for their formation and functioning. Therefore, the cohesion of the key provisions related to the legal status of both judges and presidents is assumed.

At the present stage, federal courts of general jurisdiction include general jurisdiction courts of cassation and appeal; supreme courts of the republics, courts of territories, regions, federal cities; courts of an autonomous region; courts of autonomous areas; district courts, city courts, interdistrict courts; military courts; specialized courts. Justices of the peace pertain to general jurisdiction courts of the constituent entities of the Russian Federation $^{1}$.

The system of general jurisdiction courts in the Russian Federation embraces not only federal courts of general jurisdiction but also general jurisdiction courts of the constituent entities of the Russian Federation, which include justices of the peace. Therefore, at present, one should note that issues of interaction between the presidents of the relevant federal courts of general jurisdiction and justices of the peace are not thoroughly studied by scientists in regard to the matter of leading the organization and activities of the latter.

At the end of 2020, there were only 2343 federal courts of general jurisdiction ${ }^{2}$. That is why the principle of unity in establishing these courts is of great importance, which, in turn, implies general approaches to determining the legal status of presidents of general jurisdiction courts.

The functioning and development of the judicial system of the Russian Federation, as defined by the legislation on the organization of the judiciary and judicial proceedings, are aimed at achieving the sole goal of the administration of fair justice carried out by an independent, competent, impartial and legitimate court.

At the same time, respect for the principle of the unity of the judiciary system and the independence of the judiciary power ensures the co-direction of such development, avoiding significant deviations in both organizational and procedural terms. In this regard, on December 27, 2012, the Government of the Russian Federation issued Resolution No. 1406 to approve the Federal Target Program entitled "The Development of the Judicial System in Russia for 2013-2020", which in December 2020 was extended until 2024³. It aims to raise the quality of the administration of justice and improve judicial protection of citizens and organizations' rights and legitimate interests.

${ }^{1}$ Federal Constitutional Law No. 1-FKZ on Courts of General Jurisdiction in the Russian Federation dated 7 February 2011 (hereinafter, references to Russian normative legal acts are provided according to the SPS “Consul'tantPlius”. Accessed March 23, 2021. http://www.consultant.ru).

${ }^{2}$ Report of the Director General of the Judicial Department to the Plenary Session of the Council of Judges of the Russian Federation on December 8, 2020.

${ }^{3}$ Resolution No. 1406 of the Government of the Russian Federation on the Federal Target Program entitled "The Development of the Judicial System in Russia for 2013-2020" dated 27 December 2012 (as amended on December 29, 2020). 
The legal status of the president of a general jurisdiction court has a uniform legal nature and certain features similar to the legal status of presidents of arbitration courts, constitutional (statutory) courts of the constituent entities of the Russian Federation, as well as presidents of higher courts (the Supreme Court of the Russian Federation, the Constitutional Court of the Russian Federation).

At the same time, the multifaceted character of the legal status of the president of a general jurisdiction court expressed in the combination of the status of the head of the court with all its features and the independent status of the judge administering justice, as well as in the presence of special procedural, organizational, managerial and representative powers, plays a pivotal role in understanding the issue under study. Thus, the court president has specific procedural powers to expedite judicial proceedings ${ }^{4}$, as well as powers to contribute to the security of judges of the relevant court, organize court proceedings, interact with other courts, bodies of the judicial community, state authorities and the public to ensure high quality administration of independent justice.

The post of the president of a general jurisdiction court requires extensive managerial powers, including the direct supervision of judges, economic and administrative activities (construction, repair, public procurement, etc.), control of clerks and other services.

Since 1996, the presidents of courts, except for the highest ones, have been appointed by the President of the Russian Federation for six-year terms with the right of reassignment. This gives rise to a variety of assessments, including negative ones. For example, E. A. Trofimov described this as a process of building a vertically organized system of political relations that contradict the principle of separation of powers (Trofimov 2014, 203). However, according to another point of view, the system of appointing all federal judges, including court presidents, is relatively consistent with both the tradition established in the post-Soviet period and foreign experience (Shablinskii 2016, 99).

Due to the lack of precise legislative regulation, there is no clear understanding and requirement for candidates for presidents of general jurisdiction courts, as well as for the president himself: the tasks and principles of his activities, especially when it comes to the termination of his powers as the president not related to those ones as a judge.

Besides, the legal status of the president directly depends on the place of the court he heads in the hierarchy of general jurisdiction courts as a whole and, accordingly, it affects the peculiarities of its acquisition (termination), the breadth of the powers of a particular president of a general jurisdiction court.

A comprehensive study and further scientific justification of the elements of the legal status of presidents of general jurisdiction courts are necessary since their role in the context of the organization and activities of the Russian judicial system is significantly increasing.

\section{Basic research}

Although the definition of "legal status" has received considerable attention in legal literature, discussions are still underway on its substantive elements and relationship with other categories.

${ }^{4}$ For example, according to Article 6.1 of the Code of Civil Procedure of the Russian Federation 2002, Article 6.1 of the Code of Criminal Procedure of the Russian Federation 2001. 
In addressing this issue, researchers face a range of challenges.

The first one, which began to develop in the 1960 s of the $20^{\text {th }}$ century and became independent in the 1970s, is the relationship between the concepts of "legal status" and "legal position". Two main approaches stand out: either matching these categories and recognizing them as synonyms (Lepeshkin 1966, 56; Kornukov 1987, 16; Voevodin 1997, 298; Tatarinova 2015; Porsiurov 2017) since the Latin word "status" is translated as a position, state (Basik 2005, 24), or considering legal status as a structural element of the legal position laid down in the works of V.A.Kuchinskii (Kuchinskii 1978, 113-115) and N. V. Vitruk (Vitruk 1979, 28-29).

In the second approach, the meaning of legal status in its definition is also interpreted differently. Thus, D.N. Gorshunov believes that the legal status is a static side of the legal position (cit. ex Porsiurov 2017, 167). V. V. Lazarev considers the legal position as the sum of legal and any other statuses - industrial, special one, etc. (Lazarev 2001).

The second challenge is the distinction between "legal status" and "legal position". One should note that G. Jellinek spoke about these categories back in the late $19^{\text {th }}-$ early $20^{\text {th }}$ centuries; he identified four states of legal status: passive, active, positive and negative (Jellinek 1903).

Modern scientists offer a slightly different approach. These terms have many common features: they have a regulative and formally defined nature, characterize the legal position of the subject in society and reflect the complex of his legal capabilities and connections. The main difference is that the holders of legal status can be exclusively subjects of law, and the range of carriers of legal status is much broader. These are not only subjects but also objects of law, social relations and processes (Novikova 2013, 12). If the legal status outlines possible and necessary boundaries of conduct, defines rights and obligations, then the legal state is their specific manifestation. As S.S. Alekseev noted, status is something that is stable, fundamental in the legal state of the subject (Alekseev 1982, 142-143).

A third challenge concerns the structure of legal status. Various concepts attempt to reveal the meaning of legal status in a broad as well as narrow sense, but the appropriate point of view appears to be that of M. A. Avdeenkova and Iu. A. Dmitriev. They believe that the elements of legal status interlink and interact with each other: the procedure for acquiring a legal status and its loss; a set of rights and obligations; guarantees; legal states; responsibility (Avdeenkova, Dmitriev 2004).

Finally, the fourth challenge is the classification of legal statuses according to various criteria. Concerning the legal status of the court president, the most important is the division of legal statuses into professional and titular ones (Basik 2005, 26) since, on the one hand, the president of a general jurisdiction court is a judge who holds pleas, on the other hand, an individual who directs the activities of the court apparatus.

Speaking about the post of court president, the term "legal status" seems to be more appropriate than "legal position" or "legal state" since such an approach allows us to consider the rights and obligations strictly defined by law in statistics and dynamics and the place of the court president and judges relative to each other in legal relations and ties existing in the state (Redkikh 2009).

When describing the legal status of the president of a general jurisdiction court, it is critical to take into account several provisions.

First, the primary category for determining the legal status of the president of a general jurisdiction court is the legal status of a judge since its loss automatically means the 
termination of the powers of the court president. Researchers present the elements of the judge's legal status and their combination in different ways.

Let us give three points of view on this issue.

The first one envisages that the legal status of a judge consists of: 1) the rights and obligations related to the formation of the judiciary, namely the requirements for candidates for the post of judge, the rules for their selection and the granting of judicial powers; 2) rights and obligations of judges ensuring their independence (particular procedure for suspension and termination of powers, benefits upon resignation, etc.); 3) rights and obligations that ensure the participation of judges in judicial self-government bodies (Gutsenko, Kovalev 2002, 226).

According to the second point of view proposed by E. B. Abrosimova in the book entitled Judicial Power, the legal status of a judge includes four elements: the procedure for election or appointment; features of legal status that distinguish judges from other holders of state power; the competence of judges; termination procedure (Petrukhin 2003, 564).

The third point of view also supports the idea of four-element structures of the legal status of a judge, but it includes taking office (the moment of taking the oath, from now on the status of a judge is actually acquired); the competence of judges to exercise judicial powers; guarantees of judicial activity (independence, inviolability, social and material security, irremovability, etc.); disciplinary, administrative and criminal liability of judges (Sigitov 2016).

Since the legal status is not limited only to rights and duties, and the termination of powers is an important characteristic when considering the legal status of the president of the court in dynamics, it seems preferable to distinguish five elements such as: 1) the procedure for appointment; 2) judicial guarantees that determine the features of the legal status of the court president compared to other holders of state power; 3) competence of the court president; 4) procedure for termination of activity; 5) responsibility.

Secondly, though the legal status of the president of a general jurisdiction court is derived from the legal status of a judge, it has significant differences since a judge is assumed to have experience in professional activities, unique personal qualities, organizational and communicative skills, etc. Therefore, it is necessary to consider the professional and titular legal status of the court president.

Since the definition of legal status always entails legal consolidation (Zinov'ev 1987, 8-9; Choguldurov 2015, 162), let us consider the normative legal framework, which is the basis of the elements of a judge's legal status in general and the president of a court of general jurisdiction in particular.

Guarantees of judicial activity determining the characteristics of the legal status, which distinguish judges in general and the court president in particular from other holders of state power, stem from the principles of organization and administration of justice.

Despite the significance of these principles, these are only their doctrinal definitions.

Thus, N. N. Efremova understands the principles of justice at the present stage as the main principles of the organization and functioning of judicial authorities, which are enshrined in the Constitution of the Russian Federation and international legal instruments (Efremova 2019, 31).

V. I. Anishina, emphasizing the democratic nature of the principles of justice, notes that they are the primary provisions that ensure a fair and legitimate resolution of court cases to protect a person and a citizen, the population, as well as other subjects of legal re- 
lations in need of judicial protection of their interests and determine the most significant aspects of state activity (Anishina et al. 2006, 38).

The features of the principles of justice are their legislative consolidation, objective nature (they should reflect the laws of the organization of the judiciary, as well as the legal and ethical ideas prevailing in society at this stage of historical development), ability to reflect the most common approaches in the organization of the courts, the guiding nature of the provisions, and ability to establish legal liability for their violation (Larin, Kuz'min 2005, 12).

The essential characteristics of the principles of the organization and administration of justice are manifested in the fact that these are the ideological democratic foundations of justice which are generally binding norms of law and reflect both the specifics of the Russian legal system and the judiciary (Nevolina 2018, 170).

The constitutional principles of the organization and administration of justice are enshrined in chapter 1 entitled "The Basis of the Constitutional System" and chapter 7 "Judicial Authority" of the Constitution of the Russian Federation ${ }^{5}$.

The first principle is the administration of justice exclusively by judicial bodies the Constitutional and Supreme Courts, federal courts of general jurisdiction, arbitration and justice of the peace courts of the constituent entities of the Russian Federation (Article 118).

The second principle is the establishment of special requirements for the judiciary: the mandatory educational qualification for judges, which was absent in Soviet times, upon reaching a certain age, the absence of citizenship of another country and accounts in foreign banks (Article 119).

The third is the principle of the independence of the judiciary and judges, which at the present stage is the fundamental basis of modern justice.

Thus, Article 10 of Chapter 1 of the Constitution of the Russian Federation of 1993 establishes the principle of independence of the legislative, executive and judicial powers. However, in subsequent chapters, such a characteristic as independence is inherent only in the latter. This is determined by the fact that the judicial power is implemented in a special form - a form of justice (Balashova 2017, 123).

The principle of the independence of the judiciary and judges is multifaceted. It addresses the challenges of the free persuasion of judges in assessing evidence, the existence of an effective system of legal guarantees that ensures the legal status of the court and judges, the subordination of judges only to the law, etc.

At the present stage, it is necessary to distinguish several features of the consolidation and interpretation of this principle.

Over the centuries, the principle of court independence has developed. However, having become constitutional, it gradually transformed into the principle of independence of judges and the principle of independence of the judiciary (Levchenko 2014, 116). For example, modern Russian researchers believe that the independence of judges is determined by the level of self-consciousness of a particular person and is developed while a man forms as an individual (Ermoshin 2016,20). Gradually, the independence of judges began to be recognized not just as a constitutional norm but as a constitutional value (Kirlanov 2008). Thus, this principle is translated into the field of axiology of law. At the same

${ }^{5}$ The Constitution of the Russian Federation (adopted following the nationwide vote on December 12, 1993 with amendments supported during the All-Russian vote on July 1, 2020). 
time, over the past years, there has been a constant discussion about improving Article 120 of the Constitution of the Russian Federation, various revisions were proposed (Kornev 2013), but in 2020 it was not amended. The point of view that the idea of the independence of the judiciary is organizationally well developed has prevailed (Ershov 2016, 388).

The ceremony of the court hearing filled with numerous symbolic actions is recognized as a mandatory element in maintaining the independence of judges. This was detailed by the famous American lawyer H. Berman (1918-2007), the author of the concept of integrative jurisprudence, which incorporated the provisions of the theory of natural law, legal positivism and the historical school of law. He wrote, "It is striking that... stressed the effect upon himself, as a judge, of the symbols of office - the robes, the furniture of the courtroom, the rhetoric of respect... Thus, the great ideals of legal justice are dramatized: objectivity, impartiality, consistency, equality, fairness. As the English say, justice must not only be done, it must also be seen to be done" (Berman 2000, 9).

Significant attention is paid to the self-government of the judicial community in the framework of the independence of the judiciary and judges (Balabkin 2012). Judicial codes of ethics have been introduced in different countries, revealing standards of conduct that allow the implementation of the principle of independence of judges as holders of judicial power. As noted by E. V. Burdina, in Russia, the emergence of judicial community bodies became possible only at the present stage, when guarantees of the independence and autonomy of the courts were legally enshrined (Burdina 2013, 64).

Bringing people's representatives to justice is no longer considered a "universal panacea" and a way of ensuring the judiciary's independence. As H. Berman wrote, no one had managed to prove that the jury made a better decision (cit. ex Bastrykin 2003). Many Russian scientists have a similar point of view. For example, S. I.Zakhartsev notes that through the institution of jurors, law, as it were, does not trust its own standards and establishes a procedure for their verification by non-lawyers (Zakhartsev 2013, 145).

The fourth constitutional principle of the organization and administration of justice is that of irremovability of judges (Article 121 of the Constitution of the Russian Federation).

Another essential principle is the inviolability of judges, which is considered as one of the guarantees of the independence of the judiciary (Tsaraev 2003, 185). As V. V. Ershov notes, the court independence in a legal state is not an end in itself of judges, but it serves as a mandatory, vital condition for ensuring the rights and freedoms of citizens (Ershov 1992, 76-77).

The immunity of a judge is public, as it serves not personal but state and social interests and allows administering justice. Its attributes are the inviolability of the judge's personality, his residential and office premises, vehicles and baggage, the protection of the judge from outside influence, prevention of infringement upon his rights in the administration of justice, the secrecy of correspondence, telephone conversations, postal and other messages Among the most important characteristics of this principle is that the inviolability of a judge is guaranteed by law for life. Even after the expiration of his term of office, a judge cannot be held accountable for the decision and opinion expressed by the court in the judicial process (judicial indemnity (Kutukov 2019, 245)) unless the judge is found guilty of a crime. 
Openness in the administration of justice is the fifth constitutional principle of the organization and administration of justice (Article 123 of the Constitution of the Russian Federation).

Modern researchers consider this principle to be a vital element of the judicial reform being carried out in Russia (Maleshin 2006), which changes citizens' perceptions about the functioning of the judicial system (Divin 2016). The development of this principle is given great attention throughout the world. It is recognized that the openness of justice contributes to solving a number of key issues: ensuring fair resolution of disputes within a reasonable time (Trlin 2016); increasing the independence of the judges' legal status (Gimson 2020; Berggren, Gutmann 2020); eliminating any interest and corruption in the administration of justice (Bolkvadze 2020); implementing the preventive and educational functions of justice (Campeau, Levi 2019); strengthening the rule of law at a specific stage in the development of the state and the law (Kozhevnikov et al. 2019, 85); raising citizens' confidence in the court (Denison, Wedeking, Zilis 2020; Creamer, Godzimirska 2019).

In scientific research, the openness of justice is usually considered in interrelation with such principles as publicity, transparency, accessibility (Alemanno, Stefan 2014; Polley, Clifton 2015; Pozdniakov 2013). It involves raising citizens' awareness about the rules of procedure, familiarizing themselves with the texts of court decisions and their proper understanding, which is associated with the development of legal education and the establishment of additional guarantees for the implementation of judicial tasks.

Ensuring the openness of justice is becoming increasingly relevant in connection with the growing informatization of judicial activities (Costake 2001; Tokarev et al. 2019). Three groups of informatization elements are distinguished: first, ones that reflect the openness of justice and the judicial system as a whole; second, those aimed at interacting with individuals participating in the proceedings in particular cases; third, ones that ensure the activity of the court and its engagement with other state bodies (Sharifulin, Burganov, Bikmiev 2018).

Thus, the peculiarities of the legal status of the president of a general jurisdiction court in Russia are based on the fundamental constitutional principles of the organization and administration of justice. These principles are universal for the judiciary of different countries. The fact that in 2020 chapter 7 of the Constitution of the Russian Federation was amended indicates that the judicial system is developing and is increasingly interacting with society and its civil institutions. This contributes to the emergence of new requirements for the training of judges and their personal characteristics. As for court presidents, these requirements are becoming further tightened.

Other elements of the legal status of the president of a court of general jurisdiction, such as the procedure for appointing court presidents, their competence as judges and the procedure for terminating activities, are regulated by the Constitution, federal constitutional laws, federal laws, the Code of Judicial Ethics adopted by the judicial community and containing a set of moral and aesthetic rules for judges, which is referred to in the Law on the Status of Judges (Articles 12.1, 15, 20.2.), resolutions and orders of executive authorities (for example, on forms of execution writs), decisions of the All-Russian Congresses of Judges, decisions of the Council of Judges and its Presidium, rulings of the Presidium and Plenary Session of the Supreme Court of the Russian Federation, joint orders of the Chief Justice of the Supreme Court and the Judicial Department, orders of the Judicial Department, etc. 
In June 1992, the Law on the Status of Judges was adopted, earlier than the Constitution of the Russian Federation ${ }^{6}$.

Then, on December 12, 1993, the Constitution of the Russian Federation was adopted following the nationwide vote. Articles 71-124 were originally devoted to the judiciary.

In April 1995, the Federal Law on State Protection of Judges, Officials of Law Enforcement and Regulatory Bodies was adopted ${ }^{7}$.

In 1996, the Federal Constitutional Law on the Judicial System of the Russian Federation $^{8}$ was adopted to specify provisions of the Constitution.

In 1998, two federal laws on the judiciary appeared: at the beginning of the year the Law on the Judicial Department at the Supreme Court of the Russian Federation ${ }^{9}$ and in December - the Law on Justices of the Peace ${ }^{10}$.

In 1999, the Federal Constitutional Law on Military Courts of the Russian Federation was adopted ${ }^{11}$.

The issue of the legal status of general jurisdiction judges is also raised in the Federal Law on the Fundamentals of the System for the Prevention of Child Neglect and Juvenile Delinquency of $1999^{12}$.

An important step was the Federal Law on Bodies of the Judiciary in the Russian Federation of $2002^{13}$, which was adopted in the framework of the country's international obligations.

In 2004, the Federal Law on Jurors of Federal Courts of General Jurisdiction in the Russian Federation was adopted ${ }^{14}$.

In 2008, in order to improve the information component of judicial activity, the Federal Law on Ensuring Access to Information on the Activities of Courts in the Russian Federation ${ }^{15}$ was adopted.

Only in 2011 did the Federal Constitutional Law on General Jurisdiction Courts in the Russian Federation ${ }^{16}$ appear, although the activities of military courts belonging to their group, as has already been shown, were determined by the law of the same level 12 years earlier.

\footnotetext{
6 The Law No. 3132-1 on the Status of Judges dated 26 June 1992.

7 The Federal Law No. 45-FZ on State Protection of Judges, Officials of Law Enforcement and Regulatory Bodies dated 20 April 1995.

${ }^{8}$ Federal Constitutional Law No. 1-FKZ on the Judicial System of the Russian Federation dated 31 December 1996.

9 Federal Law No. 7-FZ on the Judicial Department at the Supreme Court of the Russian Federation dated 8 January 1998.

10 Federal Law No. 188-FZ on Justices of the Peace dated 17 December 1998.

11 Federal Constitutional Law No. 1-FKZ on Military Courts of the Russian Federation dated 23 June 1999.

12 Federal Law No. 120-FZ on the Fundamentals of the System for the Prevention of Child Neglect and Juvenile Delinquency dated 24 June 1999.

13 Federal Law No. 11-FZ on Bodies of the Judiciary in the Russian Federation dated 14 March 2002.

14 Federal Law No. 113-FZ on Jurors of Federal Courts of General Jurisdiction in the Russian Federation dated 20 August 2004.

15 Federal Law No. 262-FZ on Ensuring Access to Information on the Activities of Courts in the Russian Federation dated 22 December 2008.

${ }^{16}$ Federal Constitutional Law No. 1-FKZ on General Jurisdiction Courts in the Russian Federation dated 7 February 2011.
} 
The last law adopted in chronological order was the Federal Constitutional Law on the Supreme Court of the Russian Federation of $2014^{17}$.

The establishment of this sequence of enacting legislation defining the legal status of presidents of general jurisdiction courts makes it possible to draw some important conclusions.

Even before the extensive reform of the judicial system in Russia, the determination of such important elements of the legal status of a judge began, such as the requirements for judges, the selection of candidates for the post of a judge, the powers of presidents and deputy presidents of courts, the termination of powers and resignation of a judge, material support for judges, symbols of judicial power, etc.

After the adoption of the Constitution of the Russian Federation, which defined the general requirements for judges and such principles of their activities as independence, irremovability, inviolability, and openness, the tendency to legislate state guarantees for the protection of judges continued.

Since 1996, a new stage has begun, connected with the formation of the judicial system of the Russian Federation when the requirements and powers of the presidents of separate courts began to be specified.

In parallel, since the late 1990s, the legal status of judges of general jurisdiction has begun to be influenced by additional factors that found legislative consolidation: the priority of protecting children's rights, formation of corporate norms of the judicial community, the need to interact with civil society institutions to ensure information openness in the activities of the courts, etc.

Of course, there was logic in such a sequence of adopting laws, but it gave rise to several serious problems.

On the one hand, the constitutional provisions governing the legal status of general jurisdiction judges are disclosed in more detail in federal constitutional and federal laws, but, on the other hand, there is a constant duplication.

Constitutional provisions tend to be stated in stricter requirements for judges and court presidents. Thus, according to Article 119 of the Russian Federation Constitution, judges may be citizens of Russia who are at least 25 years of age, have a higher legal education, and have worked in the legal profession for at least five years. Thus, Article 4 of the Law on the Status of Judges of the Russian Federation specifies the requirements for higher legal education: higher legal education in "Law" or higher education in "Law" with a "master's" degree (qualification) accompanied by a bachelor's degree in "Law"18.

The work of military courts belonging to the courts of general jurisdiction is regulated by the same federal constitutional law as the activities of general jurisdiction courts as a whole, which creates specific challenges in determining the hierarchy of sources that will be discussed further.

This situation leads to a number of challenges.

Firstly, there is no list of these documents of different rank, and at times differing in content, in terms of requirements for court presidents. This seriously complicates the work of the presidents of general jurisdiction courts, since sometimes it is difficult to establish

${ }^{17}$ Federal Constitutional Law No. 3-FKZ on the Supreme Court of the Russian Federation dated 5 February 2014.

${ }^{18}$ Law of the Russian Federation No. 3132-1 on the Status of Judges of the Russian Federation dated 26 June 1992 (amended as of December 8, 2020). 
a hierarchy of sources where there are international legal standards of both a mandatory and advisory nature, normative legal acts of various levels, judicial decisions, documents of the judicial community, etc.

Secondly, as already noted, many issues of determining the legal status of presidents of general jurisdiction courts are duplicated in many sources. On the one hand, this leads to consistency of the source base, but on the other hand, it indicates that this topic is not sufficiently developed.

Thirdly, the term of reference for court presidents can be determined in documents that, at first glance, regulate completely different types of public relations: Federal Law on Enforcement Proceedings ${ }^{19}$, Federal Law on Combating Corruption ${ }^{20}$, Federal Law on the Fundamentals of the System for the Prevention of Child Neglect and Juvenile Delinquency ${ }^{21}$, etc. This results in a situation where it is difficult for court presidents to navigate.

\section{Conclusions}

The legal status of the president of a general jurisdiction court guarantees the implementation of the principle of justice independence and has a complex dual nature since the court president is a judge participating in cases (professional status) and the organizer of judicial activities (titular status). The structure of the legal status of the court president has its own differences. It consists of such elements as the procedure for appointment, guarantees of judicial activity determining the peculiarities of the legal status of the court president compared to other holders of state power, the competence of the court president, the procedure for termination of activity, and responsibility.

This structure of the legal status of the court president, depending on the combination of its elements, allows us to distinguish three models, based on the main area of the court president's:

1) organizational model, in which the court president is considered as "primus inter pares"; he organizes the work of the court but bases his activities on the principle of independence and irremovability of judges;

2) control and supervision model, which involves broad powers of court presidents against judges, monitoring their activities and the ability to impose disciplinary sanctions on them;

3) the supervisory and administrative model, in which the court president is considered as the employer of judges.

The reform of the post of the president of a general jurisdiction court in the Russian Federation corresponds to the first model.

At the present stage, steps are being taken to ensure greater independence of judges, thereby, part of the powers of court presidents, which may affect the independence of judges in the administration of justice or the independence of court presidents themselves who are subjects of civil law relations while conducting economic activities, is transferred

19 Federal Law No. 229-FZ on Enforcement Proceedings dated 2 October 2007 (amended as of December 22, 2020).

${ }^{20}$ Federal Law No. 273-FZ on Combating Corruption dated 25 December 2008 (amended as of July 31, 2020).

${ }^{21}$ Federal Law No. 120-FZ on the Fundamentals of the System for the Prevention of Child Neglect and Juvenile Delinquency dated 24 June 1999 (amended as of April 24, 2020). 
to the newly created institution of district court administrators and judicial community bodies (appointment and disciplinary responsibility of judges). Further reform may be related to: 1) the transfer of all powers of the presidents of regional, cassation, appeal and military courts in the field of economic activities to managers, with the introduction of such a post in all general jurisdiction courts; 2) the transfer of all powers to conduct inspections on the appeals of citizens and legal entities to the bodies of the judicial community; 3 ) the adoption of the new Federal Constitutional Law on the Status of Judges to comply with the principle of unity of the status of a judge; 4) the introduction of a mandatory requirement for candidates for the post of the president of a general jurisdiction court based on the experience of judicial work; 5) the testing of organizational and other skills necessary for the manager during competitive selection; 6) the introduction of disciplinary responsibility of court presidents for minor violations in organizational activities with the preservation of the status of the head of the court, dividing the violations into those that lead either to the deprivation of the status of the court president, or to an admonition, warning or demotion in the qualification class.

\section{References}

Alekseev, Sergei S. 1982. General theory of law. Moscow, Iuridicheskaia literatura Publ. (In Russian)

Alemanno, Alberto, Oana Stefan. 2014. "Openness at the Court of Justice of the European Union: Toppling a taboo". Common Market Law Review 51 (1): 97-139.

Anishina, Vera I., Elena B. Abrosimova, Gadis A. Gadzhiev, Grigorii T. Ermoshin, Vladimir E. Safonov. 2006. Independence and autonomy of the judiciary of the Russian Federation. Moscow, Iurist" Publ. (In Russian)

Avdeenkova, Mariia. P., Iurii A. Dmitriev. 2004. “The concept of the basis of the legal status of a person and a citizen”. Pravo i zhizn' 2 (66): 34-37. (In Russian)

Balabkin, Sergei I. 2012. "Self-government of the judicial community as a guarantee of the independence of judges". Pravo i politika 12: 2181-2189. (In Russian)

Balashova, Irina, N. 2017. "The principle of independence of judges and obedience only to the law as a fundamental principle of civil procedure law". Aktual'nye problemy razvitiia grazhdanskogo prava i grazhdanskogo protsessa. Materialy Vserossiiskoi nauchno-prakticheskoi konferentsii, posviashchennoi 40-letiiu universiteta, 123-128. Krasnodar, Krasnodarskii universitet MVD Rossiiskoi Federatsii Publ. (In Russian)

Basik, Vladimir P. 2005. "Evolution of legal status of personality and its reflection in Russian legal science". Izvestiia vysshikh uchebnykh zavedenii. Pravovedenie 1 (258): 21-35. (In Russian)

Bastrykin, Aleksandr I. 2003. "Jury trial in Russia: dreams and reality". Accessed December 1, 2019. http:// viperson.ru/articles/aleksandr-bastrykin-sud-prisyazhnyh-v-rossii-mechty-i-realnost. (In Russian)

Berggren, Niclas, Jerg Gutmann. 2020. "Securing personal freedom through institutions: the role of electoral democracy and judicial independence". European Journal of Law and Economics 49 (2): 165-186.

Berman, Harold J. 2000. Faith and Order: The Reconciliation of Law and Religion. Grand Rapids, W. B. Eerdmans Publ.

Bolkvadze, Ketevan. 2020. "To reform or to retain? Politicians' incentives to clean up corrupt courts in hybrid regimes". Comparative Political Studies 53 (3-4): 500-530.

Burdina, Elena V. 2013. "The development of philosophical and legal ideas about the independence of judges and the independence of courts as a factor in the formation of the bodies of the judicial community". Sotsial'no-politicheskie nauki 3: 64-68. (In Russian)

Campeau, Holly, Ron Levi. 2019. "Neoliberal legality as dual process: Embeddedness, courts and crime prevention in the United States". British Journal of Criminology 59 (4): 334-353.

Choguldurov, Salamat B. 2015 "Legal status of a person (citizen) and family and legal status of a citizen as general and special categories". Evraziiskii Soiuz Uchenykh. Iuridicheskie nauki 8 (17): 161-163. (In Russian) 
Costake, Nicolae. 2001. "E-Governance and the judicial system. A point of view". The proceedings of the $12^{\text {th }}$ International conference on Database and Expert Systems Applications (DEXA), Munich, Germany, September 3-7, 2001, 423-427. Los Alamos, California, IEEE Computer Society.

Creamer, Cosette, Zuzanna Godzimirska. 2019. "Trust in the court: The role of the registry of the European Court of Human Rights". European Journal of International Law 30 (2): 665-687.

Denison, Alexander, Justin Wedeking, Michael A.Zilis. 2020. "Negative media coverage of the Supreme Court: The interactive role of opinion language, coalition size, and ideological signals". Social Science Quarterly 101 (1): 121-143.

Divin, Igor' M. 2016. "Justice openness and modern information technology". Administrator suda 3: 9-11. (In Russian)

Efremova, Nadezhda N. 2019. "Constitutional foundations of the judiciary in the Russian Federation as a factor in the progress of the domestic organization of justice". Konstitutsiia i obshchestvennyi progress. Vtorye Prokopevevkie chteniia. Materialy mezhdunarodnoi nauchno-prakticheskoi konferentsii, 29-34. Kaliningrad, Baltiiskii federal'nyi universitet imeni Immanuila Kanta Publ. (In Russian)

Ermoshin, Grigorii T. 2016. "Status of a judge in the Russian Federation”. Dr. Sci. diss., Rossiiskii gosudarstvennyi universitet pravosudiia. (In Russian)

Ershov, Valentin V. 1992. Status of the court in the legal State. Moscow, Vserossiiskii gosudarstvennyi universitet iustitsii (RPA Miniusta Rossii) Publ. (In Russian)

Ershov, Valentin V., ed. 2016. Organization of judicial activities. Moscow, Rossiiskii gosudarstvennyi universitet pravosudiia Publ. (In Russian)

Gimson, Rachel. 2020. “The rise of judicial diplomacy in the UK: Aims and challenges”. Legal studies 40 (1): $113-130$.

Gutsenko, Konstantin F., Mikhail A.Kovalev. 2002. Law enforcement bodies. $7^{\text {th }}$ ed. Moscow, Zertsalo-M Publ. (In Russian)

Jellinek, Georg. 1903. The Law of the Modern State. Vol. 1. St. Petersburg, Tovarishchestvo "Obshchestvennaia pol'za" Publ. (In Russian)

Kirlanov, Timur G. 2008. "Independence of judges as a constitutional value". Administrator suda 4: 24-31. (In Russian)

Kornev, Viktor N. 2013. "The legal nature and content of the constitutional principle of the independence of judges”. Rossiiskoe pravosudie 12 (92): 23-30. (In Russian)

Kornukov, Vladimir M. 1987. Constitutional basis for the position of the individual in criminal proceedings. Saratov, Saratovskii universitet Publ. (In Russian)

Kozhevnikov, Oleg, Alexey Romanov, Anna Gubareva, Ksenya Kovalenko. 2019. “The role of the Constitutional Court of the Russian Federation in the formation of legislation on administrative offences and ensuring the operation of the principle of legality throughout the Russian Federation". Dilemas contemporaneos: educacion, politica y valores 7: 1-9. https://doi.org/10.46377/dilemas.v29i1.1909.

Kuchinskii, Vladimir A. 1978. Personality, freedom, law. Moscow, Iuridicheskaia literatura Publ. (In Russian)

Kutukov, Anatolii D. 2019. "Constitutional principles of independence and irremovability of judges as the basis of the legal status of a judge of the Russian Federation". Molodoi uchenyi 48 (286): 243-245. (In Russian)

Larin, Aleksandr Iu., Dmitrii I. Kuz'min. 2005. Judiciary and law enforcement bodies. Moscow, Rossiiskaia gosudarstvennaia akademiia intellektual'noi sobstvennosti Publ. (In Russian)

Lazarev, Valerii V., ed. 2001. General theory of law and state. Moscow, Iurist” Publ. (In Russian)

Lepeshkin, Aleksei I. 1966. Legal status of Soviet citizens. Moscow, Mysl' Publ. (In Russian)

Levchenko, Viacheslav E. 2014. "The principle of independence of judges as a constitutional guarantee of objectivity and fairness in the settlement of disputes in civil proceedings". Vlast' Zakona 1 (17): 114120. (In Russian)

Maleshin, Dmitrii Ia. 2006. “Concept of Justice Openness Reform”. Zakonodatel'stvo 5: 45-53. (In Russian)

Nevolina, Ol'ga V. 2018. "Constitutional principles of the organization and functioning of justice in the Russian Federation”. Molodoi uchenyi 45 (231): 170-172. (In Russian)

Novikova, Iuliia S. 2013. "Some issues of distinction between 'legal position' and 'legal status"' Vestnik Iuzhno-Ural'skogo gosudarstvennogo universiteta. Seriia "Pravo" 13 (3): 12-14. (In Russian)

Petrukhin, Igor' L., ed. 2003. The Judiciary. Moscow, OOO TK Velbi Publ. (In Russian) 
Polley, Romina, Michael J. Clifton. 2015. “The principles of transparency and openness, and access to documents”. The Handbook of EEA Law, 625-656. Cham (ZG), Springer International Publishing Switzerland AG.

Porsiurov, Egor A. 2017. "On the relationship between 'legal status' and 'legal status' of the individual". Elektronnyi nauchnyi zhurnal 3-2 (18): 166-168. (In Russian)

Pozdniakov, Mikhail L. 2013. Problems of the practical implementation of the principle of openness of justice in the Russian Federation. St. Petersburg, Institut problem pravoprimeneniia pri Evropeiskom universitete v Sankt-Peterburge Publ. (In Russian)

Redkikh, Sergei V. 2009. "Concept of legal status: formal and legal context". Probely v rossiiskom zakonodatel'stve 3: 42-44. (In Russian)

Shablinskii, Il'ia G. 2016. "Judiciary and political regime in Russia: some aspects of interaction". Politicheskaia kontseptologiia 4: 94-107. (In Russian)

Sharifulin, Ramil' A., Ramis S. Burganov, Ramil' G. Bikmiev. 2018. “Elements of e-justice”. Rossiiskii sud'ia 6: 57-62. (In Russian)

Sigitov, Timofei M., ed. 2016. The challenges of the development of modern science: a collection of scientific articles on the materials of the II International Scientific and Practical Conference (October 20, 2016, Perm). Perm, IP Sigitov T.M. Publ. (In Russian)

Tatarinova, Elena P. 2015. "Relationship between personal civil status and legal personality". Nauchnaia diskussiia: voprosy iurisprudentsii 6-7 (35): 27-31. (In Russian)

Tokarev, Dmitry A., Viktoria A. Usanova, Natalya Kagalnitskova, Viktoria A. Sandalova. 2019. “Development of E-Justice in Russia: Modernization of legal regulation and deepening of scientific research. Ubiquitous computing and the internet of things: Prerequisites for the development of ICT". Studies in Computational Intelligence 826: 215-222.

Trlin, Davor. 2016. "Judicial control of public administration in Bosnia and Herzegovina and the rule of law". Croatian and Comparative Public Administration 16 (3): 587-608.

Trofimov, Evgenii A. 2014. "Russian policy and hierarchy of the internal organization of the court: on the issue of appointing court presidents". Gumanitarnye, sotsial'no-ekonomicheskie i obshchestvennye nauki 7: 202-204. (In Russian)

Tsaraev, Arsen A. 2003. "Immunity of the judge as a guarantee of his independence". PhD diss., Institut mezhdunarodnogo prava i ekonomiki imeni A.S. Griboedova. (In Russian)

Vitruk, Nikolai V. 1979. Fundamentals of the theory of the legal position of the individual in socialist society. Moscow, Nauka Publ. (In Russian)

Voevodin, Leonid D. 1997. Legal status of an individual in Russia. Textbook. Moscow, Moskovskii gosudarstvennyi universitet Publ., INFRA-M: Norma Publ. (In Russian)

Zakhartsev, Sergei I. 2013. "Jury trial as a problem of justice: philosophical, legal and applied aspects". Mir politiki i sotsiologii 9: 144-151. (In Russian)

Zinov'ev, Aleksandr V. 1987. Status of a People's Deputy of the USSR (problems of theory and practice). Leningrad, Leningradskii gosudarstvennyi universitet Publ. (In Russian)

Received: May 26, 2021

Accepted: September 2, 2021

Authors' information:

Yaroslav B.Zholobov - Associate Professor; zholobov@szfrgup.ru

Viktor N.Kornev — Dr. Sci. in Law, Professor; prorector_nauka@rsuj.ru 